\title{
The amino acid supplementation of barley for the growing pig
}

\section{Optimal additions of lysine and threonine for growth}

\author{
BY M. F. FULLER, I. MENNIE AND R. M. J. CROFTS \\ Rowett Research Institute, Bucksburn, Aberdeen AB2 $9 S B$
}

(Received 20 April 1978 - Accepted 20 July 1978)

\begin{abstract}
I. Thirty-three diets were made by adding to ground barley combinations of $\mathrm{L}-\mathrm{lysine}(0-6 \cdot 0 \mathrm{~g} / \mathrm{kg})$ and L-threonine $(0-3.0 \mathrm{~g} / \mathrm{kg})$, together with vitamins and minerals. Each was given to two female and two castrated male pigs during their growth from 25 to $60 \mathrm{~kg}$.

2. Growth rate increased from $0.36 \mathrm{~kg} / \mathrm{d}$ to a maximum of $0.65 \mathrm{~kg} / \mathrm{d}$ with additions of $3.8 \mathrm{~g} \mathrm{~L}-\mathrm{lysine} / \mathrm{kg}$ and $\mathrm{I} .8 \mathrm{~g}$ L-threonine $/ \mathrm{kg}$; these values and the maximum gains achieved were slightly higher for castrates than for females. Minimum values for food conversion ratio of 2.84 for castrates and 3.06 for females were achieved with similar amino acid additions to those giving fastest growth.

3. Carcass fat, estimated by specific gravity, was least with the addition of $5.9 \mathrm{~g} \mathrm{~L}-\mathrm{lysine} / \mathrm{kg}$, but continued to decrease up to the highest threonine concentrations. Backfat thickness was also reduced by amino acid additions but failed to reach a minimum.
\end{abstract}

Cereal grains form the basis of diets for pigs in many parts of the world, and particularly in industrialized countries. Such diets are completed by the addition of foodstuffs supplying vitamins and minerals and additional protein. The purpose of the additional protein is twofold; to increase the total protein supply and to remedy the amino acid deficiencies of the cereal protein. Ideally, the supplementary protein should bring the total amount of protein and its amino acid balance to the point where the animal's needs are exactly met. The success of this is limited in two ways; first by limitations of the available foodstuffs and secondly by uncertainties about the amino acid requirements of pigs.

We have determined the additions of amino acids required to optimize the utilization of barley protein by growing pigs in a series of experiments in which urinary nitrogen excretion was used as the criterion of protein utilization (Fuller et al. I 978). It was found that addition of the first- and second-limiting amino acids, lysine and threonine, accounted for most of the attainable improvement. In these experiments, addition of $4.0 \mathrm{~g} \mathrm{~L}$-lysine $/ \mathrm{kg}$ and $\mathrm{of} \mathrm{I} \cdot 2 \mathrm{~g}$ $\mathrm{L}$-threonine $/ \mathrm{kg}$, raising the total concentrations to approximately $7 \cdot 2$ and $4.2 \mathrm{~g} / \mathrm{kg}$, minimized urinary $\mathrm{N}$ excretion.

The present experiment was designed to examine two further aspects: first, whether the commercially-important measures of pig growth could be improved to the same extent as $\mathrm{N}$ metabolism by the same amino acid additions; second, to examine the form of the response to determine what improvements in pig performance could be obtained with smaller additions of amino acids.

\section{EXPERIMENTAL}

Design. Thirty-three diets were formed by adding graded amounts of lysine and threonine to a basal diet in an incomplete factorial arrangement which is shown in Table 1 . The design was replicated twice with a total of sixty-six castrated male pigs and sixty-six females.

Diets and feeding. The basal diet, described in Table 2, consisted of ground barley with vitamins and minerals. The barley was the same as that used in Expts 4 and 5 described in the previous paper (Fuller et al. 1979). It was taken from one 30-tonne batch and repeatedly mixed. Each batch of the basal diet ( 2 tonnes) was divided into two halves, one without added lysine, the other with added lysine, $6.0 \mathrm{~g} / \mathrm{kg}$, as the monohydrochloride. Each of these 
Table I. Design of the experiment

(Diets in the series A-F had no lysine added: diets G-L had $6.0 \mathrm{~g}$ lysine $/ \mathrm{kg}$. Final diets were made by mixing pairs of equal threonine content. The values indicate the numbers of females and males respectively which completed the experiments)

\begin{tabular}{|c|c|c|c|c|c|}
\hline Diet: Without lysine & $\mathbf{A}$ & B & C & D & E \\
\hline With $6.0 \mathrm{~g}$ lysine $/ \mathrm{kg} \quad \ldots$ & $\mathbf{G}$ & $\mathbf{H}$ & I & $\mathbf{J}$ & K \\
\hline $\begin{array}{l}\mathrm{L} \text {-threonine added }(\mathrm{g} / \mathrm{kg}) \quad \ldots \\
\mathrm{L}-\text { lysine added }(\mathrm{g} / \mathrm{kg})\end{array}$ & o & 0.6 & $1 \cdot 2$ & $1 \cdot 8$ & $2 \cdot 4$ \\
\hline 0 & 2.2 & $2 \cdot 1$ & $2 \cdot I$ & - & - \\
\hline 10 & $2 \cdot 2$ & 2.2 & $2 \cdot 2$ & $2 \cdot 2$ & - \\
\hline 2.0 & $2 \cdot 2$ & $2 \cdot 2$ & $3 \cdot I$ & 2.2 & $2 \cdot I$ \\
\hline 3.0 & $2 \cdot 2$ & 2.2 & $2 \cdot 2$ & $2 \cdot 2$ & $2 \cdot 2$ \\
\hline 4.0 & $I \cdot 2$ & 2.2 & $2 \cdot 2$ & $2 \cdot 3$ & I. 2 \\
\hline 50 & - & $2 \cdot 2$ & $2 \cdot 2$ & $2 \cdot 2$ & $2 \cdot 2$ \\
\hline 6.0 & - & - & $2 \cdot 2$ & 2.2 & $2 \cdot 2$ \\
\hline
\end{tabular}

Table 2. Composition ( $\mathrm{kg} /$ tonne) of the basal diet

Ingredients

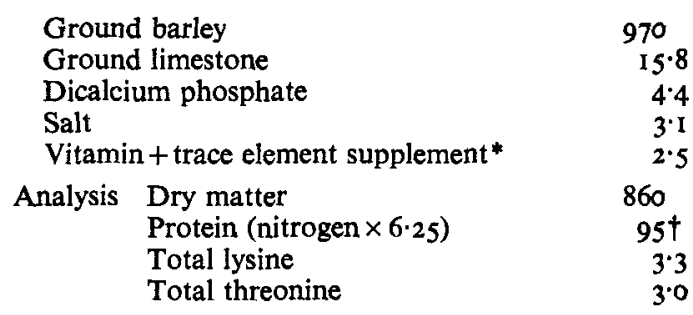

\footnotetext{
* Parkhill supplement (Spencer's Feed Supplements, Dyce, Aberdeen) supplying (/1000 kg diet): retinol $300 \mathrm{mg}$, cholecalciferol $25 \mathrm{mg}$, ribofiavin $2 \mathrm{~g}$, DL-calcium pantothenate $10 \mathrm{~g}$, nicotinic acid $10 \mathrm{~g}$, cyanocobalamin $5 \mathrm{mg}$ menaphthone $9 \mathrm{~g}$, copper $200 \mathrm{~g}$, zinc $100 \mathrm{~g}$, manganese $30 \mathrm{~g}$, iron $60 \mathrm{~g}$, cobalt $0.9 \mathrm{~g}$, iodine I g.

+ Containing $(\mathrm{g} / \mathrm{l} 60 \mathrm{~g} \mathrm{~N})$ : threonine $30 \cdot 0$, valine $48 \cdot 0$, isoleucine $33 \cdot 8$, leucine 63.4 , tyrosine 33.3 , phenylalanine $41^{\circ} \cdot 4$, histidine $19 \cdot 7$, lysine 35.2 , methionine 17.5 , cystine 23.4 , tryptophan 9.8 . (For details of amino acid analysis, see Fuller et al. 1979.)
}

was subdivided into six portions to each of which $\mathrm{L}$-threonine was added at one of the chosen levels. This provided six diets (diets A-F) with no added lysine and six more (diets G-L) with the maximum amount of lysine added. Final diets were made by weighing a portion of each of a pair of diets (diets $A+G, \ldots$ diets $F+L$ ) for each meal. All diets were given at the rate of $\mathrm{I} 20 \mathrm{~g} / \mathrm{kg}^{0.75}$ per $\mathrm{d}$, adjusted once per week when animals were weighed.

Animals. Sixty-six female and sixty-six castrated male pigs were selected when they reached $20 \mathrm{~kg}$ in groups of eleven of the same sex, three such groups of each sex forming one block. They were the progeny of Large White boars and Large White $\times$ Landrace sows. They were allocated at random to the diets and fed individually twice daily. Five pigs refused significant amounts of food during the experiment and were discarded. Two animals were inadvertently allocated to the wrong treatments. The number of males and females completing the experiment on each diet is shown in Table $\mathbf{I}$.

Measurements. Each animal was weighed on three successive days when it reached approximately $25 \mathrm{~kg}$ and again when it reached approximately $60 \mathrm{~kg}$. The animal was then slaughtered. The carcass was split and measurements were made of backfat thickness of each side at the shoulder, mid-back and loin (Harrington, 1958) and by optical probe over the last rib at points $P_{1}, P_{2}$ and $P_{3}, 45,60$ and $80 \mathrm{~mm}$ from the mid-line respectively (Meat and 
Table 3. Average daily gains $(\mathrm{kg})$ of pigs given a barley diet with additions of lysine and threonine

\begin{tabular}{|c|c|c|c|c|c|c|}
\hline \multirow{2}{*}{$\begin{array}{l}\text { Added lysine } \\
\text { (g/k diet) }\end{array}$} & \multicolumn{6}{|c|}{$\begin{array}{l}\text { Added threonine } \\
\text { (g/kg diet) }\end{array}$} \\
\hline & $\circ$ & 0.6 & $I \cdot 2$ & $\mathrm{I} \cdot 8$ & $2 \cdot 4$ & 3.0 \\
\hline & \multicolumn{6}{|c|}{ (a) Males } \\
\hline 0 & 0.41 & 0.45 & 0.52 & - & - & - \\
\hline 1.0 & 0.47 & 0.50 & $0.5 \mathrm{I}$ & 0.53 & - & - \\
\hline 2.0 & 0.52 & 0.62 & 0.59 & 0.59 & 0.64 & - \\
\hline 3.0 & 0.46 & 0.59 & 0.64 & 0.63 & 0.64 & 0.67 \\
\hline 4.0 & 0.46 & 0.62 & 0.64 & 0.65 & 0.66 & 0.64 \\
\hline \multirow{4}{*}{$\begin{array}{l}5.0 \\
6.0\end{array}$} & - & 0.60 & 0.68 & 0.58 & 0.63 & 0.60 \\
\hline & - & - & 0.62 & 0.64 & 0.60 & 0.68 \\
\hline & \multicolumn{6}{|c|}{ Over-all mean 0.590} \\
\hline & \multicolumn{6}{|c|}{ (b) Females } \\
\hline 0 & 0.32 & 0.35 & 0.33 & - & 一 & - \\
\hline 1.0 & 0.46 & 0.48 & 0.52 & 0.39 & - & - \\
\hline 2.0 & 0.36 & 0.53 & 0.63 & 0.57 & 0.64 & - \\
\hline $3 \cdot 0$ & 0.43 & 0.55 & 0.58 & 0.60 & 0.63 & 0.63 \\
\hline 4.0 & 0.45 & 0.48 & 0.58 & 0.64 & 0.67 & 0.60 \\
\hline 5.0 & - & 0.55 & 0.65 & 0.64 & 0.60 & 0.46 \\
\hline 6.0 & - & - & 0.55 & 0.61 & 0.52 & 0.57 \\
\hline
\end{tabular}

Over-all mean 0.534

Livestock Commission, I 97I). The specific gravity (SG) of each side was measured by weighing it in air and in water. For each measurement the mean value for the two sides was used.

Analysis of results. Responses to amino acid concentrations were examined by multiple regression analysis, using the logarithms of the variables. Rosenberg et al. (1959) used an equation of this form to analyse their similar experiments with rats, though they did not state whether the fit of their values was improved by logarithmic transformation. With our results there was a small, but non-significant improvement in fit: the major effect of the logarithmic transformation was to make the analysis more sensitive to the interaction between lysine and threonine, as evidenced by the significant product term in several of the equations. In some instances, square and product terms were not significant and were omitted.

\section{RESULTS}

There were no significant differences between the two blocks in any of the measurements. Only in the instance of the daily gain did differences between males and females in the regression coefficients approach significance. In all instances there was a highly significant difference $(P<0.001)$ between the sexes in the adjusted mean of each of the measured variables.

Daily gain. The average daily gain of males and females on each diet is given in Table 3 . Over-all, castrates grew faster than females; this difference was greatest with the low-quality diets. Although differences between the sexes in the regression coefficients were not quite significant, use of the pooled coefficients underestimated the maximum gain of the females and concealed the fact, evident from inspection of individual values, that their gain decreased more rapidly with increases of lysine above the optimum than that of males. Separate regression equations were therefore calculated for males and females and are given in Table 7. From these, a maximum daily gain for gilts of $0.64 \mathrm{~kg}$ is predicted with an addition 


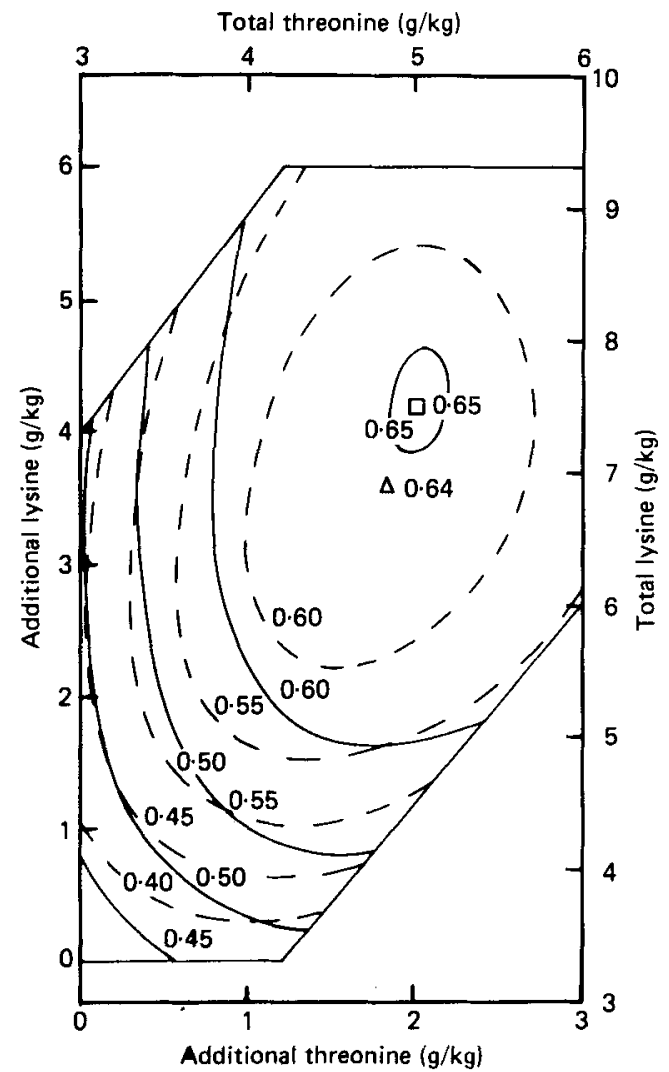

Fig. I

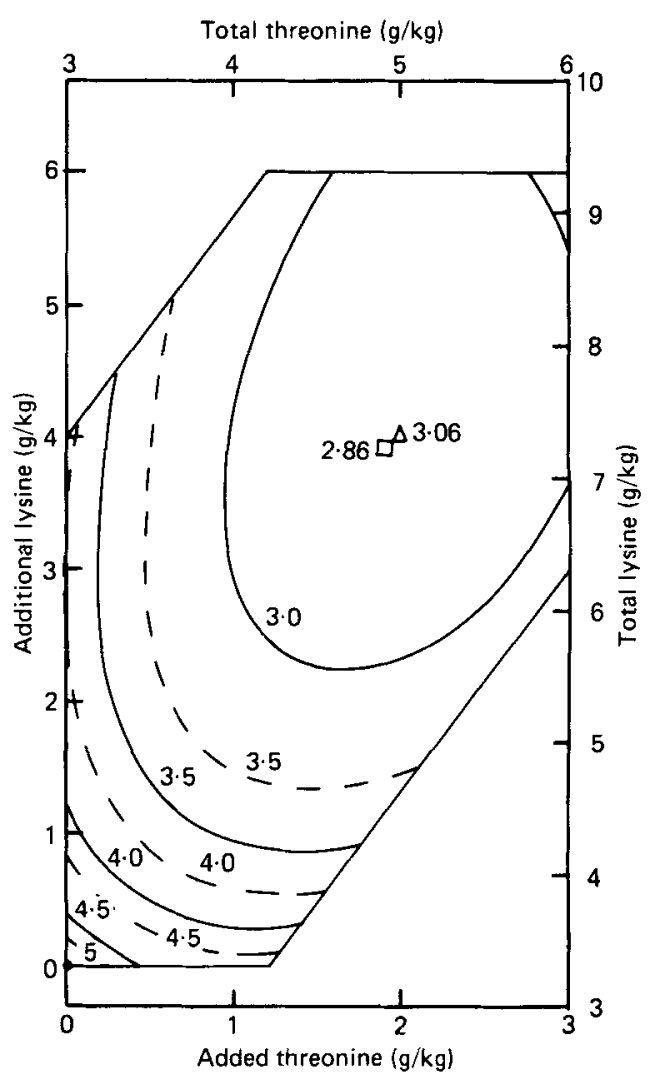

Fig. 2

Fig. I. The daily gains $(\mathrm{kg})$ of pigs in response to the supplementation of a barley diet with lysine and threonine. The lines are contours of equal gain: $(\square),(-), \delta^{*} ;(\triangle),(---)$, ㅇ.

Fig. 2. The food conversion ratio (FCR; $\mathrm{kg}$ food / $\mathrm{kg}$ weight gain) of pigs in response to the supplementation of a barley diet with lysine and threonine. The lines are contours of equal FCR: ( $\square$ ), $(-), \delta^{*} ;(\triangle),(--)$, ㅇ․

of $3.5 \mathrm{~g}$ lysine $/ \mathrm{kg}$ and of $\mathrm{I} .8 \mathrm{~g}$ threonine $/ \mathrm{kg}$. For castrates the maximum gain of $0.65 \mathrm{~kg}$ was achieved with additions of $4.2 \mathrm{~g}$ lysine $/ \mathrm{kg}$ and $2.0 \mathrm{~g}$ threonine $/ \mathrm{kg}$. Thus, the gilts achieved a maximum growth rate almost as high as the castrates with slightly lower additions of amino acids; with smaller quantities of amino acids added, however, their growth rate declined considerably more than that of the castrates. Fig. I presents these results in the form of gain isoquants, describing combinations of lysine and threonine at which equal growth rates were achieved.

Food conversion ratio $(F C R)$. The mean FCR for each diet is given in Table 4. The pooled within-sex regression coefficients relating FCR to the concentrations of lysine and threonine are given in Table 7. Males achieved a minimum FCR of 2.84 and females 3.06 . These were obtained with additions of $4.0 \mathrm{~g}$ lysine $/ \mathrm{kg}$ and $\mathrm{I} \cdot 9 \mathrm{~g}$ threonine $/ \mathrm{kg}$. The FCR isoquants are shown in Fig. 2.

Carcass SG. Estimates of carcass SG are given in Table 5. Males had a maximum SG, corresponding to a minimum fatness, of $\mathrm{I} \cdot 053$ and females $\mathrm{I} \cdot 057$. These were attained with the addition of $5.9 \mathrm{~g}$ lysine $/ \mathrm{kg}$ and the maximum addition of $3.0 \mathrm{~g}$ threonine $/ \mathrm{kg}$. The results suggested a continued response to threonine above this, the highest concentration included. 
Table 4. Food conversion ( $\mathrm{kg}$ food/ $\mathrm{kg}$ weight gain) of pigs given a barley diet with additions of lysine and threonine

\begin{tabular}{|c|c|c|c|c|c|c|}
\hline \multirow{2}{*}{$\begin{array}{l}\text { Added lysine } \\
\text { (g/kg diet) }\end{array}$} & \multicolumn{6}{|c|}{$\begin{array}{l}\text { Added threonine } \\
\text { (g/kg diet) }\end{array}$} \\
\hline & 0 & 0.6 & $\mathrm{I} \cdot \mathbf{2}$ & $\mathrm{I} \cdot 8$ & 2.4 & 3.0 \\
\hline $\begin{array}{l}0 \\
1 \cdot 0\end{array}$ & $\begin{array}{l}5.00 \\
4.08\end{array}$ & $\begin{array}{l}4.67 \\
3 \cdot 75\end{array}$ & $\begin{array}{l}4 \cdot 66 \\
3 \cdot 70\end{array}$ & $\frac{-}{3 \cdot 99}$ & $\overline{-}$ & $\overline{-}$ \\
\hline $\begin{array}{l}2 \cdot 0 \\
3 \cdot 0\end{array}$ & $\begin{array}{l}4 \cdot 29 \\
4 \cdot 12\end{array}$ & $\begin{array}{l}3 \cdot 28 \\
3 \cdot 28\end{array}$ & $\begin{array}{l}3.13 \\
3.09\end{array}$ & $\begin{array}{l}3.21 \\
3.06\end{array}$ & $\begin{array}{l}3.05 \\
2.98\end{array}$ & $\overline{2.91}$ \\
\hline $\begin{array}{l}4 \cdot 0 \\
5 \cdot 0\end{array}$ & $\begin{array}{c}3.87 \\
-\end{array}$ & $\begin{array}{l}3.40 \\
3.28\end{array}$ & $\begin{array}{l}3 \cdot 07 \\
2 \cdot 87\end{array}$ & $\begin{array}{l}2 \cdot 93 \\
3 \cdot 10\end{array}$ & $\begin{array}{l}2 \cdot 88 \\
3 \cdot 06\end{array}$ & $\begin{array}{l}3.04 \\
3.43\end{array}$ \\
\hline 6.0 & - & - & $3 \cdot 12$ & 3.04 & 3.23 & $3 \cdot 12$ \\
\hline
\end{tabular}

Over-all means: of 3.256, of $3 \cdot 569$.

Table 5. The specific gravity of the carcasses of $60 \mathrm{~kg}$ pigs given, from 25 to $60 \mathrm{~kg}$, a barley diet supplemented with lysine and threonine

(For convenience, values of specific gravity are expressed by subtracting I 0 and multiplying by $10^{*}$ )

\begin{tabular}{ccccccc}
\multicolumn{7}{c}{$\begin{array}{c}\text { Added threonine } \\
\text { (g/kg diet) }\end{array}$} \\
\cline { 2 - 7 } (g/kg diet) & 0 & $0 \cdot 6$ & $1 \cdot 2$ & $1 \cdot 8$ & $2 \cdot 4$ & $3 \cdot 0$ \\
0 & 382 & 364 & 348 & - & - & - \\
$1 \cdot 0$ & 420 & 438 & 437 & 455 & - & - \\
$2 \cdot 0$ & 427 & 468 & 484 & 503 & 528 & - \\
$3 \cdot 0$ & 439 & 489 & 520 & 598 & 534 & 552 \\
$4 \cdot 0$ & 414 & 478 & 522 & 499 & 517 & 537 \\
$5 \cdot 0$ & - & 520 & 535 & 525 & 531 & 554 \\
$6 \cdot 0$ & - & - & 548 & 496 & 530 & 542
\end{tabular}

Over-all means: $\delta 475$, ㅇ 501 .

Table 6. The backfat thickness $(\mathrm{mm})$ at point $\mathrm{P}_{2}$ (60 mm from mid-line) of $60 \mathrm{~kg}$ pigs given, from 25 to $60 \mathrm{~kg}$, a barley diet with supplements of lysine and threonine

Added threonine

$\begin{array}{ccccccc}\begin{array}{c}\text { Added lysine } \\ (\mathrm{g} / \mathrm{kg} \text { diet })\end{array} & 0 & 0.6 & 1.2 & 1.8 & 2.4 & 3.0 \\ 0 & 19.2 & 19.3 & 20.0 & - & - & - \\ 1.0 & 18.8 & 19.5 & 18.0 & 17.3 & - & - \\ 2.0 & 20.2 & 15.5 & 18.5 & 15.7 & 17.0 & - \\ 3.0 & 17.3 & 16.8 & 16.7 & 16.3 & 16.0 & 14.3 \\ 4.0 & 20.0 & 17.3 & 15.0 & 15.0 & 16.3 & 16.0 \\ 5.0 & - & 14.5 & 16.7 & 15.8 & 17.5 & 14.8 \\ 6.0 & - & - & 15.3 & 17.0 & 15.0 & 14.7\end{array}$

Over-all means: $o^{*}$ I $7 \cdot 93,+9$ 15.86.

The regression equations describing these relationships are given in Table 7 . Isoquants of carcass SG in relation to lysine and threonine concentrations are shown in Fig. 3.

Backfat thickness. All backfat measurements decreased with increasing additions of lysine up to the maximum supplement, with no discernible optimum. Optical probe measurements 
Total threonine $(\mathrm{g} / \mathrm{kg})$

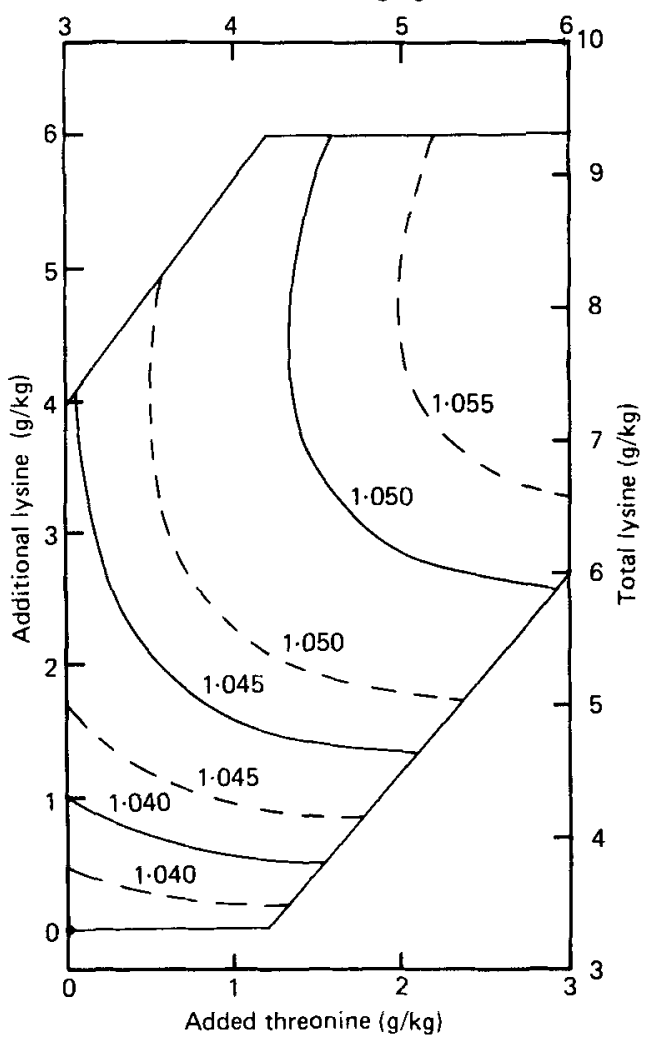

Fig. 3. The carcass specific gravity of pigs in response to the supplementation of a barley diet with lysine and threonine. The lines are contours of equal specific gravity: $(-), \delta ;(-\cdots), q$.

Table 7. Regressions of the natural logarithms of the measured variates on the logarithms of the concentrations of total lysine $(L ; \mathrm{g} / \mathrm{kg})$ and total threonine $(T ; \mathrm{g} / \mathrm{kg})$

\begin{tabular}{|c|c|c|c|}
\hline Dependent variate & Sex & Regression equation & $\begin{array}{l}\text { Resiaua } \\
\text { SD }\end{array}$ \\
\hline $\log _{e}$ daily wt gain $(\mathrm{kg})$ & $\begin{array}{l}0 \\
0 \\
+\end{array}$ & $\begin{array}{l}-4.287+1.497 \mathrm{~L}+2.909 \mathrm{~T}-0.475 \mathrm{~L}^{2}-\mathrm{I} .065 \mathrm{~T}^{2}+0.26 \mathrm{I} \mathrm{LT} \\
-6.754+3.177 \mathrm{~L}+4.122 \mathrm{~T}-\mathrm{I} \cdot 178 \mathrm{~L}^{2}-\mathrm{I} .871 \mathrm{~T}^{2}+0.889 \mathrm{LT}\end{array}$ & $\begin{array}{l}0.103 \\
0.134\end{array}$ \\
\hline $\log _{e}$ FCR & $\begin{array}{l}0 \\
0 \\
+\end{array}$ & $\left.\begin{array}{l}5.366 \\
5.436\end{array}\right\}-2.053 \mathrm{~L}-2.86 \mathrm{I} T+0.712 \mathrm{~L}^{2}+1.208 \mathrm{~T}^{2}-0.493 \mathrm{LT}$ & 0.093 \\
\hline $\log _{e} S G$ & $\begin{array}{l}0 \\
\stackrel{+}{q}\end{array}$ & $\left.\begin{array}{l}-4.240 \\
-4.304\end{array}\right\}+\mathrm{I} \cdot 440 \mathrm{~L}+0.429 \mathrm{~T}-0.448 \mathrm{~L}^{2}-0.245 \mathrm{~T}^{2}+0.267 \mathrm{LT}$ & 0.063 \\
\hline $\log _{e} P_{2}(\mathrm{~mm})$ & $\begin{array}{l}0 \\
q\end{array}$ & $\left.\begin{array}{l}3.4 \mathrm{II} \\
3.297\end{array}\right\}-0.170 \mathrm{~L}-0.163 \mathrm{~T}$ & 0.175 \\
\hline
\end{tabular}

FCR, food conversion ratio ( $\mathrm{kg}$ food $/ \mathrm{kg}$ wt gain); $\mathrm{SG}$ specific gravity; $P_{2}$, back fat thickness $60 \mathrm{~mm}$ from the mid-line.

were reduced with additions of both lysine and threonine, but no optimum dose of either amino acid was detected within the range used in the experiment. The optical probe measurement at point $P_{2}$ has been taken as representative of backfat thickness and is given in Table 6 . The regression relating backfat thickness at $P_{2}$ to the amino acid concentrations is given in Table 7 . 


\section{DISCUSSION}

These results confirm in principle what was reported in the previous paper (Fuller et al. 1978); that substantial improvements in the utilization of cereal protein can be achieved by the simultaneous addition of just two amino acids. There are, however, two aspects of the results which were not anticipated from the earlier work and which particularly demand discussion. The first is that the threonine concentration required for maximum daily gain and minimum FCR was $4.9 \mathrm{~g} / \mathrm{kg}$, which is $16 \%$ higher than was required to minimize urinary $\mathrm{N}$ excretion. The optimal lysine concentrations, on the other hand, were similar in the two studies. Reference to Figs. I and 2, however, suggests that the discrepancy is not serious. In each instance the point of optimum response is seen to lie within a broad area of lysine and threonine combinations over which large changes in amino acid concentration produce only small changes in response. Similarly, when urinary $\mathrm{N}$ excretion was the criterion, the optimal threonine concentration was judged to be that beyond which further additions produced no significant response. This is likely to underestimate the concentration giving maximum response.

Müller et al. ( 1967 ) gave pigs a mixture of cereals including $440 \mathrm{~g}$ barley $/ \mathrm{kg}$. They found in two similar trials that faster growth was achieved with the addition of $2.0 \mathrm{~g}$ threonine $/ \mathrm{kg}$ than with $\mathrm{I} \cdot 0 \mathrm{~g} / \mathrm{kg}$; giving an optimum threonine addition very similar to that found in the present experiment. They did not, however, give the amino acid composition of their basal diet, which is likely to affect the responses to amino acid additions. This is illustrated by the results of Aw-Yong \& Beames (I975), who found that pigs given a barley diet with added lysine $3.5 \mathrm{~g} / \mathrm{kg}$ (total $7.5 \mathrm{~g} / \mathrm{kg}$ ) gained faster with the addition of threonine $1.0 \mathrm{~g} / \mathrm{kg}$ than with 0.5 or $1.5 \mathrm{~g} / \mathrm{kg}$. Their barley, however, had a higher threonine content than ours, and their optimal diet had a total threonine concentration of $4.7 \mathrm{~g} / \mathrm{kg}$, similar to the estimate of $4.9 \mathrm{~g} / \mathrm{kg}$ in the present experiment. The concentrations of lysine and threonine in their optimal diet amounted to 6.8 and $4.3 \mathrm{~g} / \mathrm{kg}$ protein, which are very similar to the values of $7 . \mathrm{I}$ and $4.2 \mathrm{~g} / \mathrm{kg}$ protein which are reported in the previous paper (Fuller et al. 1978).

The second aspect which requires discussion is the observation that measures of carcass leanness continued to respond to additions of amino acids above those giving the fastest and most efficient growth. This implies that with additions of amino acids above those giving maximum growth decreases in lean tissue growth were accompanied by even greater declines in the rate of fat deposition. There is no obvious explanation for this. A decrease in fat deposition might be expected had the animals been fed ad lib. for then excessive amino acids might depress food consumption with resultant reductions in both daily gain and backfat thickness (Aw-Yong \& Beames, I975). In the present experiment animals were given fixed amounts of food which, in all but a few instances, was completely eaten. It is perhaps worth noting, however, that four of the five animals which refused significant amounts of food, and which were discarded from the experiment, were given diets with, as it transpired, an excess of threonine relative to lysine. An analogous response to increasing protein concentration was noted in a review of the literature by the Agricultural Research Council (1967). Improvements in carcass quality were seen with increases in protein concentration above those giving maximum weight gain and most efficient food conversion. In that instance, however, increases in protein concentration involve simultaneous reduction in the supply of non-protein energy, with a consequent reduction in the net energy of the diet (Schiemann, I963). There seems to be no evidence that a small excess of amino acids could affect the net energy of the diet. As the effect was seen in both the specific gravity and the backfat thickness measurements, it appears to be real, and may be of significance in determining what amino acid supplements are economically optimal. 
The generosity of Ajinomoto Co. Inc., Tokyo, Japan in donating the amino acids is acknowledged with gratitude. The authors are indebted to the staff of the Duthie Experimental Farm for their care of the animals, and to Mr K. Pennie and Mr A. R. Pirie for making some of the measurements.

\section{REFERENCES}

Agricultural Research Council (I967). The Nutrient Requirements of Farm Livestock No. 3 Pigs. London: Agricultural Research Council.

Aw-Yong, L. M. \& Beames, R. M. (1975). Can. J. Anim. Sci. 55, 765.

Fuller, M. F., Livingstone, R. M., Baird, B. A. \& Atkinson, T. (1979). Br. J. Nutr. 4r, 32 I.

Harrington, G. (1958). Tech. Commun. Commonw. Bur. Anim. Breed. Genet. no. 12, p. 5.

Meat and Livestock Commission (1971). Pig Carcass Classification. London: Meat and Livestock Commission.

Müller, Z., Kozel, V., Bauer, B., Strunc, M. \& Moravec, J. (1967). Biol. Chem. Vyzivy Zvirat 5, 399.

Rosenberg, H. R., Culik, R. \& Eckert, R. E. (1959). J. Nutr. 69, 217.

Schiemann, R. (1963). Sber, dt. Akad. LandWiss. 12, 50. 